\title{
INVESTIGATING LEAD AND ZINC UPTAKE AND ACCUMULATION BY STIPA HOHENACKERIANA TRIN AND RUPR. IN FIELD AND POT EXPERIMENTS
}

\author{
INVESTIGAÇÃO SOBRE A CAPTAÇÃO E ACÚMULO DE CHUMBO E ZINCO POR \\ Stipa hohenackeriana TRIN. \& RUPR. EM EXPERIMENTOS DE CAMPO E EM VASO
}

\author{
Mehdi MOAMERI ${ }^{1}$; Mohammad JAFARI ${ }^{2}$; Ali TAVILI ${ }^{3} *$ Babak MOTASHAREZADEH $^{4}$; \\ Mohammad Ali ZARE CHAHOUKI ${ }^{2}$; Fernando Madrid DIAZ ${ }^{5}$ \\ 1- Assistant Professor, University of Mohaghegh Ardabili, Ardabil, Iran; 2- Professor, University of Tehran, Karaj, Iran; $3^{*}$-Associate \\ Professor, University of Tehran, Karaj, Iran. atavili@ut.ac.ir; 4- Associate Professor, University of Tehran, Karaj, Iran; 5- Técnico \\ Superior Especializado de los OPIs, IRNAS-CSIC, Spain.
}

\begin{abstract}
This study was conducted to evaluate $\mathrm{Pb}$ and $\mathrm{Zn}$ uptake, mobility, and accumulation in Stipa hohenackeriana using field soil in pot and field experiments. Moreover, the effects of Municipal Solid Waste Compost (MSWC) $(0,1$, and 2\%) and Nano-Silica (NS) $(0,250$, and $500 \mathrm{mg} / \mathrm{kg}$ ) on Stipa biomass, Pb and Zn availability in the soil, and $\mathrm{Pb}$ and $\mathrm{Zn}$ uptake and accumulation were studied using pot experiments. Samples of soil, root, and shoots of Stipa were collected from field and greenhouse and after drying, extraction of $\mathrm{Pb}$ and $\mathrm{Zn}$ was done by acid digestion. BioConcentration Factor (BCF) and Translocation Factor (TF) were calculated to determine $\mathrm{Pb}$ and $\mathrm{Zn}$ phytoremediation efficiency. The amount of $\mathrm{Zn}$ and $\mathrm{Pb}$ remediation by Stipa from soil was determined by remediation factor (RF). The results of field experiments showed the $\mathrm{Pb}$ and $\mathrm{Zn}$ level decreased in the order of: soil >shoot>root. Results of the pot experiments also showed that plants grown in NS500-amended pots had 33\% and 32\% higher Pb in roots and shoots compared to control pots, respectively. In comparison, roots $\mathrm{Pb}$ concentration in pots amended with $\mathrm{MSWC} 1 \%$ and MSWC2\% decreased $22.4 \%$ and $1.7 \%$, respectively. Roots and shoots Zn concentration in NS500-amended pots was 5.6\% and $6.5 \%$ higher, respectively. However, root Zn concentration in treatments of MSWC1\% and MSWC2\% decreased $52.3 \%$ and $39.4 \%$, respectively. Shoots Zn concentration decreased 52.5\% and 40.0\%, respectively. Although MSWC decreased the uptake and accumulation of $\mathrm{Pb}$ and $\mathrm{Zn}$ in Stipa roots and shoots, it improved the plant growth and consequently increased RF and soil remediation compared to the NS. Thus, it seems that applying MSWC and NS simultaneously can be a suitable strategy for the purpose of improving phytoremediation capability of Stipa in the Pb and $\mathrm{Zn}$ contaminated soils. In general, Stipa can be a suitable candidate for the accumulation of heavy metals, especially for $\mathrm{Pb}$ and $\mathrm{Zn}$ contaminated soils.
\end{abstract}

KEYWORDS: MSWC. NS. phytoremediation. heavy metal.

\section{INTRODUCTION}

Heavy metals pollution in soils, water body, and the air is one of the world's major environmental problems, posing significant risks to human health and ecosystems. Therefore, the development of remediation strategies for contaminated soils is required for human health and ecosystems conservation. Most of the traditional methods are either highly expensive (i.e., solidification, excavation, and burial) or simply involve the isolation of the contaminated sites. Some methods, such as soil washing, can pose an adverse effect on biological activity, soil structure, and fertility (PULFORD; WATSON, 2003). In general, traditional land remediation techniques are very expensive, and result in deterioration of soil quality. Phytoremediation methods cost almost onefourth of the other traditional methods of contaminating treatment. The main benefits of phytoremediation are that it is cost effective and technically feasible, improves soil quality, promotes high rhizosphere activity, and allows restoration in a reasonable period of 2 to 3 years. Moreover, using this technique, plants serve as sufficient biomass for rapid remediation (SABEEN et al., 2013).

Lead $(\mathrm{Pb})$, as one of most widespread metal contaminants in soil, has limited bioavailability due to complexation with organic and inorganic soil colloids, sorption on clays, oxides, and precipitation as hydroxides, phosphates, and carbonate. $\mathrm{Zn}$ concentrations are generally low in soils their and total concentration is around $50 \mathrm{mgZn} / \mathrm{kg}$ (KIEKENS, 1995). At these amounts, $\mathrm{Zn}$ is sufficiently taken by plants as an essential element (MARSCHNER, 1995). $\mathrm{Zn}$ is the most widespread heavy metal pollutants in wastes arising from industrialized communities (MERTENS et al., 2004).

Using amendments to contaminated soils may be useful because they can change the behavior of heavy metals, their accessibility to plants, 
toxicity, immobilization/mobilization and leaching potential (ADRIANO et al., 2004). Sabir et al. (2015) reported that compost and farmyard manure increased the ammonium bicarbonate diethylene triamine penta acetic acid (AB-DTPA) extractable $\mathrm{Ni}$ and $\mathrm{Mn}$ in the soil and decreased $\mathrm{Cu}$ and $\mathrm{Zn}$. Alvarenga et al., (2009) reported that mixed MSWC could be successfully used in the remediation of a contaminated mine soils. Besides, it can correct soil $\mathrm{pH}$ and increase soil $\mathrm{OM}$, total $\mathrm{N}$, available $\mathrm{P}$ and $\mathrm{K}$ to levels that improved the establishment of perennial ryegrass.

Nanomaterials form another group of effective soil amendment candidates. Due to the size of nanomaterials, they can change physicochemical soil properties and have a greater surface area more than their bulk materials. Also, considering their larger surface area, they have a higher solubility and surface reactivity (CASTIGLIONE; CERMONINI, 2009). Plants generally require silica to control biotic stress. NS is an important metal oxide that it is used in the major fields of technology and sciences including electronics, industries, and biomedicine (PAULKUMAR et al., 2012). It has gained greater attention because of its highly reactive surface-to-volume ratio property. Application of nanoparticles in agricultural is currently an interesting field of study. The introduction of nanoparticles into plants might have a significant impact and, thus, it can be used for agricultural applications for a better growth and yield. Different researchers have shown that the application of NS in the soil enhances the growth of maize (YUVAKKUMAR et al., 2013). Karunakaran et al., (2013) reported that the silica and protein content of bacterial biomass clearly showed an increase in uptake of silica with an increase in NS concentration in maize. NS promotes seed germination percentage $(100 \%)$ in maize and has a favorable effect on beneficial bacterial population and nutrient value of soil.

National Iranian Lead \& Zinc CompanyZanjan is located at $10 \mathrm{~km}$ east of Zanjan city, Iran. It has been operating since 1981. So, the surrounding soils of this Company have been contaminated with some of the heavy metals. As a result, it has caused the risks for natural ecosystems and people health of Zanjan city. Stipa is a dominant species with a wide distribution in the study area that can provide suitable biomass for absorption heavy metals. Therefore, the objective of this study is to evaluate plant uptake, $\mathrm{Pb}$ and $\mathrm{Zn}$ mobility, and accumulation of lead and zinc in Stipa using field soil in the pot with amendments of MSWC and NS were added to the soil.

\section{MATERIAL AND METHODS}

\section{Field experiment Study area description}

National Iranian Lead and Zinc Company of Zanjan is located between $36^{\circ} 36^{\prime} 40^{\prime \prime}$ and $36^{\circ} 38^{\prime} 25^{\prime \prime} \mathrm{N}$ latitudes and $48^{\circ} 37^{\prime} 33^{\prime \prime}$ and $48^{\circ} 38^{\prime} 54^{\prime \prime} \mathrm{E}$ longitudes in Zanjan province, Iran. Rangelands around covers an area of approximately 500 ha. The mean elevation of the region is $1700 \mathrm{~m}$ above sea level. The climate of the region is semi-arid and cold (SHARIFI et al., 2012). The annual rainfall ranges from 200 to $400 \mathrm{~mm}$, with an average of 300 $\mathrm{mm}$. The Average maximum temperature is 32.1 (August), while the average minimum is -7.5 (January) (MOAMERI et al., 2017).

\section{Stipa hohenackeriana description}

Stipa hohenackeriana Trin and Rupr. (Poaceae) is a species of perennial grass. The plant is a bunchgrass with culms length of $30-80 \mathrm{~cm}$. It has a strong, branched, and dense root system. The penetration depth of its roots in the soil varies from 24 to $60 \mathrm{~cm}$. In cases where the canopy cover is wider, root penetration depth also increases. It is a grass in Asia-temperate, Siberia, Soviet Middle Asia, Caucasus, western Asia, Arabia, China, and Iran (MOGHIMI, 2005). Stipa is a dominant species and with a wide distribution in the study area that can provide suitable biomass for absorption heavy metals.

\section{Plant sampling in field}

As the first step, to evaluate $\mathrm{Pb}$ and $\mathrm{Zn}$ uptake by the Stipa, $\mathrm{Pb}$ and $\mathrm{Zn}$ mobility, and accumulate of $\mathrm{Pb}$ and $\mathrm{Zn}$ in Stipa, field experiment was conducted. Plant samples were collected around the National Iranian Lead and Zinc CompanyZanjan. Sampling was conducted at 11 sites with an area of $10 \times 10 \mathrm{~m}^{2}$. The first site was randomly selected at the Company margins. Samples of root and shoots of Stipa from an area of $1 \mathrm{~m}^{2}$ along one of the diagonals sites $10 \times 10 \mathrm{~m}^{2}$ were collected by cutting all plants collected. So, from each site, 3 plant samples were taken.

\section{Plant analysis for field studies}

After transferring the plant samples to the laboratory of the faculty of natural resources (University of Tehran), they were divided into shoots and roots, washed gently with deionized distilled water for approximately $3 \mathrm{~min}$ to remove soil particles adhered to the plants. After washing, the samples were then oven-dried at 70 until the samples were completely dry (MOAMERI et al., 
2017). After drying, all plant samples were preprocessed for $\mathrm{Pb}$ and $\mathrm{Zn}$ determination by finely grinding and passing the samples through a $2 \mathrm{~mm}$ sieve. Extraction of $\mathrm{Pb}$ and $\mathrm{Zn}$ from plant samples was done by acid digestion. Plant samples digested in the di-acid mixture $(3: 1)$ of nitric acid $\left(\mathrm{HNO}_{3}\right)$ and perchloric acid ( $\mathrm{HClO}$ ) (MOAMERI et al., 2017; Ebrahimi; Madrid Diaz, 2014). The digested plants were analyzed for $\mathrm{Pb}$ and $\mathrm{Zn}$ concentrations using Inductively Coupled Plasma Optical Emission Spectroscopy "ICP-OES" (GBC Avanta, Australia).

\section{Soil sampling in field}

Three soil samples along one of the diagonals were taken from each site within the plots. In addition, other sites were systematically selected at a distance of $100 \mathrm{~m}$ from the first site. Soil samples were taken from the rooting zone $(0-20 \mathrm{~cm})$ on May 2014. At each profile, $1 \mathrm{~kg}$ of soil was collected. Samples were air-dried at room temperature for two weeks and passed through a 2 $\mathrm{mm}$ sieve to remove gravels and debris.

\section{Soil analysis for field studies}

Some soil properties including Electrical Conductivity (EC), pH, texture, Cation Exchange Capacity (CEC), Calcium carbonate equivalent (CCE) percentage, organic matter, N\%, available Potassium, and available phosphorus (Table 1) were measured by pursuing standard methods (MOAMERI et al., 2017). Then, soil samples were analyzed for total $\mathrm{Pb}$ and $\mathrm{Zn}$. The total concentration of $\mathrm{Zn}$ and $\mathrm{Pb}$ in soil samples was determined after digesting soil with $4 \mathrm{M} \mathrm{HNO}_{3}$ acid $(1: 10$ ratio) at $60 \square$ water bath for 14 hours (AMACHER; SELIM, 1994). For estimating the available concentrations of $\mathrm{Pb}$ and $\mathrm{Zn}$, soil samples were extracted by the standard DTPA-extraction method according to Lindsay and Norwell (1978) (SOLTANPOUR, 1991). Metals of $\mathrm{Zn}$ and $\mathrm{Pb}$ extracted from soil samples were determined using Inductively Coupled Plasma Optical Emission Spectroscopy "ICP-OES" (GBC Avanta, Australia).

\section{Phytoremediation Efficiency}

The mobility of the heavy metals from the soil contaminated into the roots of the plants and the ability to translocate the metals from roots to shoots were evaluated respectively by $\mathrm{BCF}$ and $\mathrm{TF}$ (LORESTANI et al., 2011). BCF and TF were calculated to determine the heavy metal phytoremediation efficiency (YOON et al., 2006). BCF expresses the ability of a plant to accumulate metal from soils and TF is the capacity of a plant to transfer metal from its roots to shoots. In this study, the $\mathrm{TF}$ and $\mathrm{BCF}$ values for $\mathrm{Pb}$ and $\mathrm{Zn}$ are given by:

$$
\begin{aligned}
& \mathrm{TF}=\left(\mathrm{M}_{\text {shoot }}\right) /\left(\mathrm{M}_{\text {root }}\right) \\
& \mathrm{BCF}_{\text {shoot }}=\left(\mathrm{M}_{\text {shoot }}\right) /\left(\mathrm{M}_{\text {soil }}\right) \\
& \mathrm{BCF}_{\text {root }}=\left(\mathrm{M}_{\text {root }}\right) /\left(\mathrm{M}_{\text {soil }}\right)
\end{aligned}
$$$$
\text { where } \mathbf{M}_{\text {shoot }} \text { and } \mathbf{M}_{\text {root }} \text { are the metal }
$$
concentrations in the shoots and roots, respectively, and $\mathrm{M}_{\text {soil }}$ is the metal concentration in the soil (YOON et al., 2006).

\section{Pot experiment}

The purpose of this step was to assess the effectiveness of Stipa to accumulation $\mathrm{Pb}$ and $\mathrm{Zn}$ in its biomass from metals contaminated soil and to evaluate the effect of MSWC and NS on $\mathrm{Pb}$ and $\mathrm{Zn}$ uptake by Stipa. The soil for the greenhouse experiment was taken from the rooting zone in rangelands surrounding National Iranian Lead \& Zinc Company-Zanjan (field) and transferred to the greenhouse of Department of Agriculture and Natural Resources, University of Tehran, Iran. This soil was air-dried for two weeks and passed through $2 \mathrm{~mm}$ sieve to remove gravels and debris. In addition, Stipa seeds were collected from the study area.

The compost amendment tested were conducted using compost obtained from the unsorted municipal solid waste MSWC. MSWC, in turn, was obtained in a composting plant near Tehran, Iran. Three replicates of MSWC were analyzed using the methodology (Table 1) previously described by Alvarenga et al., (2007). Powder of NS was supplied by Iran Polymer and Petrochemical Institute. The characteristics of NS are given in Table 1.

Table 1. Soil and amendments' properties

\begin{tabular}{lll|ll}
\hline Properties & Soil & $\begin{array}{l}\text { Municipal Solid } \\
\text { Waste Compost }\end{array}$ & Properties & Nano-Silica \\
\hline pH & 7.76 & 6.9 & Structural nature & Amorphous \\
EC (dS/m) & 0.2 & $3.66(1: 10)$ & $\begin{array}{l}\text { Purity }(\%) \\
\text { Morphology }\end{array}$ & 98 \\
$\begin{array}{l}\text { Organic matter } \\
(\%)\end{array}$ & 0.85 & 16.77 & Spherical & \\
CCE (\%) & 3.35 & - & Special surface area $\left(\mathbf{m}^{2} / \mathbf{g}\right)$ & 400 \\
CEC (meqg/100g) & 16.53 & 25.8 & Total pore volume & $200-2000$
\end{tabular}




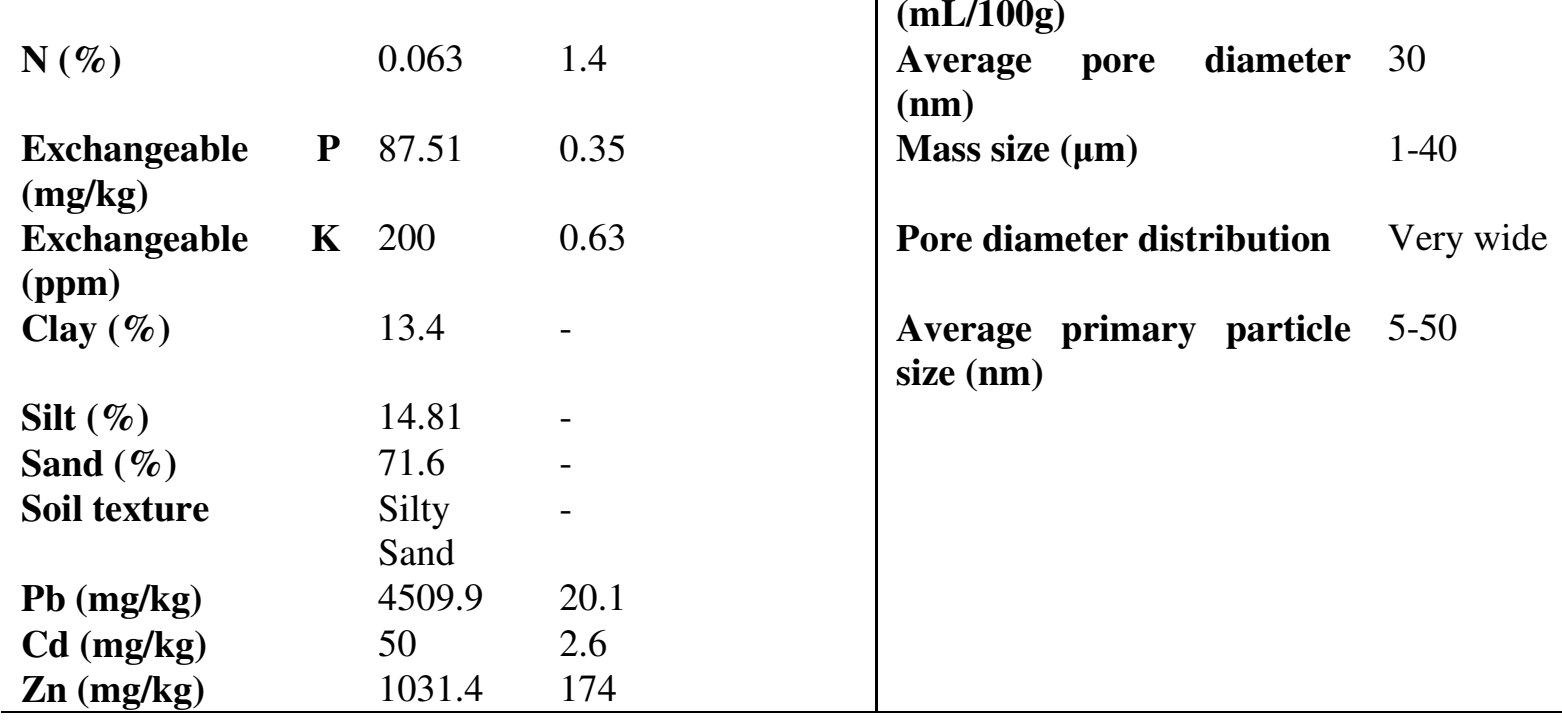

MSWC and NS were added to the soil. Treatments of MSWC were 0, 1, and 2 wt.\% of MSWC that were thoroughly mixed with soil and then $4 \mathrm{~kg}$ of this soil was added to plastic pots (diameter $15 \times$ height $20 \mathrm{~cm}$ ). Pots size was selected based on the morphology of Stipa. A filter of paper was placed at the bottom of each pot to prevent soil, $\mathrm{Pb}, \mathrm{Zn}, \mathrm{MSWC}$, and NS escaping from the drainage holes. Then, 15 seeds were buried evenly throughout each pot at least 1 to $2 \mathrm{~cm}$ from the edge with five replicates for each treatment (ABBASI KHALAKI et al., 2016).

After growing for 14 days, different doses of NS were added to the soil in the different pots based on experimental design. These treatments included soil samples amended with NS using solutions at doses of $0 \mathrm{mg} / \mathrm{kg} \mathrm{NS}, 250 \mathrm{mg} / \mathrm{kg} \mathrm{NS}$, and $500 \mathrm{mg} / \mathrm{kg}$ NS. In general, pot experiment was performed in 25 pots, including control (5 pots), MSWC1\% (5 pots), MSWC2\% (5 pots), NS $250 \mathrm{mg} / \mathrm{kg}$ (5 pots), and NS $500 \mathrm{mg} / \mathrm{kg}$ (5 pots).

The pots were watered with deionized distilled water from the top and the soil moisture content was maintained at $70 \%$ water-holding capacity. The light needed for the growth of the plants was supplied from the solar radiation. The samples were put behind the glass windows of the greenhouse and received the solar light during the experiment. The minimum and maximum temperature were 18 and $25 \square$, respectively. Throughout the growing season, plants were fertilized once a month with $300 \mathrm{mg} / 1 \mathrm{~L}$ of NPK fertilizer. Plants were grown for a period of 180 days from December 2014 to May of 2015.

Plant harvesting and metals analysis
In May 2015, after five months of growth, plants were harvested and separated into shoots and roots. The roots were rinsed with distilled water to remove the loosely bound soil. Plant samples were dried in an oven for 48 hours at $70 \square$. After recording dry shoots (SDW), roots (RDW), and total (TDW) weights, samples were ground to form a powder using Wiley Mill and digested in the di-acid mixture (3:1) of nitric acid (HNO3) and perchloric acid (HClO) (MOAMERI et al., 2017). The digested plants were analyzed for $\mathrm{Pb}$ and $\mathrm{Zn}$ concentrations using Inductively Coupled Plasma Optical Emission Spectroscopy "ICP-OES" (GBC Avanta, Australia).

After harvesting the plants, the soil samples were taken out of the pots and their physicochemical properties were determined (EC, $\mathrm{pH}$, texture, CEC, CCE\%, O.M\%, N\%, available potassium and available phosphorus) using standard methods (MOAMERI et al., 2017). Next, soil samples were analyzed for total and DTPA-exchangeable metals $(\mathrm{Pb}$ and $\mathrm{Zn})$.

\section{Remediation factor (RF)}

$\mathrm{RF}$ is defined as the ratio of an element accumulation in the shoot to that in the soil, which is calculated as follows:

$$
\mathrm{RF}(\%)=\left(\mathrm{M}_{\text {shoot }} \times \mathrm{W}_{\text {shoot }}\right) \times 100 /\left(\mathrm{M}_{\text {soil }} \times\right.
$$
$\left.\mathrm{W}_{\text {soil }}\right)$

where $\mathbf{M}_{\text {shoot }}$ is the metal concentration in shoots of the plant $(\mathrm{mg} / \mathrm{kg}), \mathrm{W}_{\text {shoot }}$ is the plant dry above ground biomass $(\mathrm{g}), \mathrm{M}_{\text {soil }}$ is the metal content of soil $(\mathrm{mg} / \mathrm{kg})$, and $\mathrm{W}_{\text {soil }}$ is the weight of soil in the pot $(\mathrm{g})$. The RF values reflect the amount of a metal remediation by a plant from soil (SUN et al., 2011).

\section{Data analysis}


The statistical processing was conducted using analysis of variance (ANOVA) technique. Before performing the analysis, data were checked for their normality with the Kolmogorov-Smirnov test and for homogeneity of variance with the Levene's test $(\mathrm{p}<0.05)$, and were long-transformed where necessary. For one-way ANOVA, Duncan's test between means was calculated only if the F-test was significant at the 0.05 level of probability. A $\mathrm{P} \leq$ 0.05 value was considered statistically significant. All statistical calculations were performed using SPSS ver.22.0. Data in the text were expressed as the mean \pm standard error.

\section{RESULTS AND DISCUSSION}

\section{$\mathrm{Pb}$ and $\mathrm{Zn}$ Concentration in the soil and Stipa} hohenackeriana in field experiment

The concentrations of $\mathrm{Pb}$ and $\mathrm{Zn}$ in soil samples collected from rangelands around the National Iranian Lead \& Zinc Company-Zanjan and in shoots and roots of Stipa are presented in Table 2. In addition, TF and $\mathrm{BCF}$ are provided. $\mathrm{BCF}$ and $\mathrm{TF}$ are two factors used to estimate a plant's potential for phytoremediation purpose. As shown in Table 2, $\mathrm{TF}>1$ for shoots and roots tested in this work. It has to be noted that when $\mathrm{TF}>1$, it shows that the accumulation of heavy metals in shoots is higher than that in the roots. The mean of TF values measured for $\mathrm{Pb}$ (1.13) indicates that Stipa may be effective as an accumulator and it is able to translocate $\mathrm{Pb}$ from roots to the shoots. $\mathrm{BCF}$ was $<1$ for $\mathrm{Pb}$ of Stipa, implying that its concentration in the Stipa shoots was greater than the roots. In general, the $\mathrm{Pb}$ level decreased in the order of soil> shoot $>$ root. The mean accumulation of $\mathrm{Zn}$ in the shoots $\left(235.8 \mathrm{mgkg}^{-1}\right)$ of the Stipa was more than that of roots $\left(202.01 \mathrm{mgkg}^{-1}\right)$. The mean TF values measured for $\mathrm{Zn}$ (1.15) indicats that Stipa would be effective for phytoremediation of $\mathrm{Zn}$. The BCF was $<1$ for $\mathrm{Zn}$ of Stipa, suggesting that $\mathrm{Zn}$ concentration in Stipa shoots was greater than that in its roots. In general, the $\mathrm{Zn}$ level decreased in the order of: soil $>$ shoot $>$ root. This plant is able to translocate $\mathrm{Zn}$ to shoots. According to Pais and Jones (1997), toxic concentrations of heavy metals for various plant species are 30 and $100 \mathrm{mg} / \mathrm{kg}$ for $\mathrm{Pb}$ and $\mathrm{Zn}$, respectively. Although, heavy metal contents in the Stipa were higher than toxic levels, the toxicsymptoms were not so severe. Tolerance to heavy metals in plants may be defined as the ability to survive in a soil that is toxic to other plants and is manifested by an interaction between a genotype and its environment (MACNAIR et al., 2000). Chelation of metals in the cytosol by high $\square$ affinity ligands is potentially a very important mechanism of heavymetal detoxification and tolerance (CLEMENS, 2001).

Table 2. $\mathrm{Pb}$ content in soil, Shoots and Roots of the $S$. hohenackeriana in field ( $\mathrm{mgkg}^{-1}$ )

\begin{tabular}{|c|c|c|c|c|c|c|c|}
\hline \multirow[t]{2}{*}{ Metals } & \multicolumn{2}{|l|}{ Soil } & \multicolumn{2}{|l|}{ Plant } & \multicolumn{2}{|c|}{$\begin{array}{l}\text { Phytoremediation } \\
\text { indexes }\end{array}$} & \multirow{2}{*}{$\begin{array}{c}\text { efficiency } \\
\mathrm{BCF}_{\text {root }} \\
\end{array}$} \\
\hline & Total & Exchangeable & Shoots & Roots & TF & $\mathrm{BCF}_{\text {shoot }}$ & \\
\hline $\mathrm{Pb}$ & $4509.9 \pm 1030.8$ & $18.35 \pm 7.2$ & $149.9 \pm 10.2$ & $132.4 \pm 10.0$ & 1.13 & 0.033 & 0.03 \\
\hline $\mathrm{Zn}$ & $1031.4 \pm 162.9$ & $13.95 \pm 5.1$ & $235.8 \pm 15.5$ & $\begin{array}{ll}202.01 & \pm \\
11.2 & \end{array}$ & 1.15 & 0.2 & 0.17 \\
\hline
\end{tabular}

Values shown are the means \pm SE. Table numbers are an average of 33 numbers.

\section{Effects of MSWC and NS on Stipa biomass in pot experiment}

MSWC and NS significantly $(\mathrm{P}<0.001)$ affected SDW, RDW, and TDW of Stipa compared to those of the control (Table 3). In this regard, MSWC increased SDW, RDW and TDW of Stipa, while NS decreased them with respect to the control. SDW was maximum (14.6 g/pot) for plants grown in pots amended with MSWC2\% while it was minimum (4.82 g/pot) in the NS500 pots. RDW and TDW were the maximum for pots treated with MSWC2\% and also were the minimum for plants amended with NS500. As shown in Table 4, MSWC due to having nutrient enhanced soil NPK increased the growth and biomass (SDW, RDW, and TDW). Moreover, MSWC increased organic matter on pots and thus enhanced plant biomass. This is consistent with the results of Moslehi et al., (2014) who reported that MSWC chelate increases plant growth and biomass and thus enhances dry weight. Sharifian et al., (2014) reported that compost as a soil amendment has a considerable effect on plant growth and yield (Marigold (Calendula officinalis Moench.) and Daisy (Bellis Perennis L.)) and increase plants growth. Wilson et al., (2004) found that in the plants cultivated in MSW compost all growth parameters are improved compared to the plants cultivated in pit. NS decreased the growth and biomass (SDW, RDW, and TDW) of Stipa. An explanation for this decrease might be the fact that NS increases $\mathrm{Pb}$ and $\mathrm{Zn}$ uptakes; as a result, the plant may be under stress and consequently, its 
growth and biomass are decreased. Le et al., (2014) reported that NS decreased significantly the plant height, shoot, and root biomasses; the $\mathrm{SiO}_{2}$ nanoparticles also affected the contents of $\mathrm{Cu}, \mathrm{Mg}$ in shoots and $\mathrm{Na}$ in roots of transgenic cotton.

Table 3. Effect of MSWC and NS on dry weights of shoots (SDW), roots (RDW) and total (TDW) (g pot ${ }^{-1}$ )

\begin{tabular}{llll}
\hline Treatments & SDW & RDW & TDW \\
\hline Control & $11.4 \pm 1.14 \mathrm{~b}$ & $7.2 \pm 1.48 \mathrm{ab}$ & $18.6 \pm 0.89 \mathrm{~b}$ \\
MSWC 1\% & $13.2 \pm 1.64 \mathrm{ab}$ & $7.4 \pm 1.14 \mathrm{ab}$ & $19.6 \pm 1.81 \mathrm{~b}$ \\
MSWC 2\% & $14.6 \pm 2.3 \mathrm{a}$ & $8.2 \pm 0.83 \mathrm{a}$ & $22.8 \pm 2.86 \mathrm{a}$ \\
NS250 (mg/kg) & $7.56 \pm 0.93 \mathrm{c}$ & $6.0 \pm 1.58 \mathrm{bc}$ & $13.56 \pm 1.47 \mathrm{c}$ \\
NS500 (mg/kg) & $4.82 \pm 1.32 \mathrm{~d}$ & $5.2 \pm 1.4 \mathrm{c}$ & $10.02 \pm 1.24 \mathrm{~d}$ \\
Duncan & $34.39^{* * *}$ & $3.7^{*}$ & $129.34^{* *}$ \\
\hline
\end{tabular}

** = significant at $\mathrm{P}<0.01, *=$ significant at $\mathrm{P}=0.01-0.05$; Mean values are reported with $\mathrm{SE}$ (Standard Error). Values within a column followed by the same letter do not differ significantly ( $\mathrm{p}<0.05$, post hoc Duncan test)

Effect of MSWC and NS on EC, pH, N, K, P, $O M$, and CEC in pot experiment

The characteristics of the soils amended with MSWC and NS were analyzed after 5 months of the experiment (Table 4). By the end of the experiment, in all experimental pots, soil $\mathrm{pH}$ values decreased as compared with control and their differences were significant $(\mathrm{p}<0.01)$. Soil $\mathrm{pH}$ was the maximum (7.57) in control while it was the minimum (6.97) in the NS500 treatment. The reason for the decrease in the $\mathrm{pH}$ is probably that hydrated silica is formed through binding the $\mathrm{Si}-\mathrm{O}$ to water molecules and hence reduces $\mathrm{pH}$. Karunakaran et al. (2013) and Iler (1979) found that nanosilica and microsilica shows a slight decrease in $\mathrm{pH}$ as they both are slightly soluble in water at ppm range, which is converted to silicon colloids because of hydrogen bonding, making them biologically active molecules. EC was low in MSWC treatments, increased in NS250 treatment it was increased as compared with control and decreased in NS500 treatment.

The total nitrogen was increased as a result of the addition of MSWC (Table 4) probably due to its nitrogen in urban waste compost. Sallami et al., (2013) reported that the total nitrogen was increased as a result of the addition of Hoagland solution and compost. In comparison, the addition of NS led to the slight increase in the soil $\mathrm{N}$, which was not significantly difference compared to the control.

MSWC and NS treatments increased soil K content and a significant difference was observed between these treatments with control $(\mathrm{p}<0.01)$. Soil $\mathrm{K}$ was the maximum (287.4 ppm) in MSWC2\%, while it was the minimum (204.2 ppm) in the control treatment. MSWC treatments increased soil
$\mathrm{P}$ content, while it did not show a significant difference between NS treatments with control $(\mathrm{p}<0.05)$. Karunakaran et al. (2013) reported that the availability of silicon sources (sodium silicate, micron silica, silicic acid, and tetraethyl silicate) might increase available nitrogen, phosphorus, and potassium (NPK) value to some extent, which is not comparable with NS. Thus, the incorporation of NS into soil enhances soil NPK values.

MSWC and NS application positively affected soil organic matter (OM) content that increased from $1.31 \%$ in control to $1.83,1.87,1.67$ and $1.83 \%$ in MSWC1\%, MSWC2\%, NS250 and NS500 treatments, respectively (Table 4). In addition, a significant difference was observed between treatments with control $(\mathrm{p}<0.01)$. OM is mainly composed of humic and fulvic substances. The complexation reaction between heavy metals and organic complexants is usually recognized as the most important reaction pathway, since this reaction largely determines the bioavailability of metals and then affects the mobility of heavy metals in the soils (PENG et al. 2009). In addition, NS affects the root rhizosphere and increases the total soil bacterial population. So, these bacteria will increase decomposition of plant material, and consequently, soil OM will could increase. MSWC application positively affected soil CEC content. Soil CEC was the maximum (19.27) in MSWC2\% while it was the minimum (17.34) in the control treatment. The CEC of different soils varies widely both in quantity and quality and can range from 1 to $100 \mathrm{meq} / 100 \mathrm{~g}$ of soils (this value of most soils does not exceed $30 \mathrm{meq} / 100 \mathrm{~g}$ ). The results showed that MSWC had a high CEC (25.8 meq/100 g) and thus increased soil CEC in the pots. 
Table 4. Influence of MSWC and NS on soil characteristics

\begin{tabular}{|c|c|c|c|c|c|c|c|c|c|c|c|c|c|}
\hline Treatments & pH & & $\begin{array}{l}\text { EC } \\
(\mathrm{ds} / \mathrm{m})\end{array}$ & & $\mathrm{N}(\%)$ & & K (ppm & & P (ppm & & OM (\% & & CEC(meq/100grsoil) \\
\hline Control & 7.57 & \pm & 2.14 & \pm & 0.07 & \pm & 204.2 & \pm & 107.6 & \pm & 1.31 & \pm & $17.34 \pm 0.15 c$ \\
\hline MSWC $1 \%$ & $\begin{array}{l}7.29 \\
0.12 b\end{array}$ & \pm & $\begin{array}{l}0.79 \\
0.05 d\end{array}$ & \pm & $\begin{array}{l}0.23 \\
0.03 a\end{array}$ & \pm & $\begin{array}{l}283.6 \\
2.7 a\end{array}$ & \pm & $\begin{array}{l}118.2 \\
5.4 b\end{array}$ & \pm & $\begin{array}{l}1.83 \\
0.05 b\end{array}$ & \pm & $18.56 \pm 0.16 b$ \\
\hline MSWC $2 \%$ & $\begin{array}{l}7.09 \\
0.09 \mathrm{c}\end{array}$ & \pm & $\begin{array}{l}0.88 \\
0.03 d\end{array}$ & \pm & $\begin{array}{l}0.1 \\
0.0 \mathrm{~b}\end{array}$ & \pm & $\begin{array}{l}287.4 \\
1.82 \mathrm{a}\end{array}$ & \pm & $\begin{array}{l}143.8 \\
4.76 \mathrm{a}\end{array}$ & \pm & $\begin{array}{l}1.87 \\
0.07 \mathrm{a}\end{array}$ & \pm & $19.27 \pm 0.1 \mathrm{a}$ \\
\hline $\begin{array}{l}\mathrm{NS} 250 \\
(\mathrm{mg} / \mathrm{kg})\end{array}$ & $\begin{array}{l}7.13 \\
0.12 b c\end{array}$ & \pm & $\begin{array}{l}3.12 \\
0.13 a\end{array}$ & \pm & $\begin{array}{l}0.09 \\
0.0 \mathrm{c}\end{array}$ & \pm & $\begin{array}{l}224.2 \\
1.92 \mathrm{c}\end{array}$ & \pm & $\begin{array}{l}107.42 \\
7.9 \mathrm{c}\end{array}$ & \pm & $\begin{array}{l}1.67 \\
0.02 \mathrm{c}\end{array}$ & \pm & $17.36 \pm 0.06 c$ \\
\hline $\begin{array}{l}\mathrm{NS} 500 \\
(\mathrm{mg} / \mathrm{kg})\end{array}$ & $\begin{array}{l}6.97 \\
0.2 c\end{array}$ & \pm & $\begin{array}{l}1.97 \\
0.09 \mathrm{c}\end{array}$ & \pm & $\begin{array}{l}0.09 \\
0.01 \mathrm{c}\end{array}$ & \pm & $\begin{array}{l}255.0 \\
9.3 b\end{array}$ & \pm & $\begin{array}{l}105.83 \\
7.1 \mathrm{c}\end{array}$ & \pm & $\begin{array}{l}1.83 \\
0.03 \mathrm{ab}\end{array}$ & \pm & $17.37 \pm 0.07 \mathrm{c}$ \\
\hline Duncan & $17.25^{* *}$ & & $451.72^{*}$ & & $0.96^{*}$ & & $286.2^{* *}$ & & $31.9^{* *}$ & & $229.8^{* *}$ & & $279.9^{* *}$ \\
\hline
\end{tabular}

** = significant at $\mathrm{P}<0.01, *=$ significant at $\mathrm{P}=0.01-0.05$; EC: Electrical Conductivity N: Nitrogen P: Phosphorus K: Potassium OM: Organic Matter CEC: Cation Exchange Capacity

\section{DTPA extractable metals in Soils in pot experiment}

Soil metals are majority found as insoluble compounds unavailable for the transport into roots that consequently affects the metal uptake by accumulating plants. MSWC and NS indicated a significant $(\mathrm{P}<0.01)$ effect on DTPA extractable $\mathrm{Pb}$ and $\mathrm{Zn}$ in the post experimental soil (Table 5). In general, the addition of MSWC and NS leads to an increase in the available $\mathrm{Pb}$ and $\mathrm{Zn}$ in soil compared to the control. The maximum extractable $\mathrm{Pb}$ (444.95 $\mathrm{mg} \mathrm{kg}^{-1}$ ) was recorded in the pots treated with NS500 that was 37\% higher compared to the control. In addition, the maximum extractable $\mathrm{Zn}$ $\left(129.6 \mathrm{mg} \mathrm{kg}^{-1}\right)$ was recorded in the pots treated with NS500 that was $20 \%$ higher compared to the control. Extractable $\mathrm{Pb}$ and $\mathrm{Zn}$ concentration in the soils increased due to the application of both MSWC and NS, irrespective of application rates. Perhaps the most important explanation for this result is the formation of a stable complex of chelates with the heavy metals and preventing their deposition in the soil. Another cause might be the increase in $\mathrm{Pb}$ and $\mathrm{Zn}$ concentrations in the soil by the use of MSWC and NS that decrease the $\mathrm{pH}$. Moslehi et al. (2014) reported that application of MSWC and EDTA (together) in the soil increased solubility and availability of $\mathrm{Pb}$ and $\mathrm{Cd}$. Peng et al. (2009) reported that a decrease in the soil $\mathrm{pH}$ results in an increase in the competition between $\mathrm{H}^{+}$and dissolved metals for ligands such as $\mathrm{CO}_{3}{ }^{2-}, \mathrm{SO}_{4}{ }^{2-}$, $\mathrm{Cl}^{-}, \mathrm{OH}^{-}, \mathrm{S}^{2-}$, and phosphates.

Table 5. Effect of MSWC and NS on extractable $\mathrm{Pb}$ in post-experiment soils

\begin{tabular}{lll}
\hline Treatments & Pb & Zn \\
\hline Control & $277.8 \pm 1.92 \mathrm{~d}$ & $102.8 \pm 1.9 \mathrm{e}$ \\
MSWC 1\% & $380.0 \pm 3.8 \mathrm{c}$ & $107.4 \pm 1.14 \mathrm{~d}$ \\
MSWC 2\% & $390.5 \pm 1.92 \mathrm{~b}$ & $111.0 \pm 1.5 \mathrm{c}$ \\
NS250 $(\mathrm{mg} / \mathrm{kg})$ & $380.6 \pm 1.51 \mathrm{c}$ & $124.8 \pm 1.9 \mathrm{~b}$ \\
NS500 $(\mathrm{mg} / \mathrm{kg})$ & $444.95 \pm 2.26 \mathrm{a}$ & $129.6 \pm 1.1 \mathrm{a}$ \\
Duncan & $311.8^{* * *}$ & $265.8^{* *}$ \\
\hline
\end{tabular}

** = significant at $\mathrm{P}<0.01, *$ * significant at $\mathrm{P}=0.01-0.05$; Mean values are reported with $\mathrm{SE}$ (Standard Error). Values within a column followed by the same letter do not differ significantly $(\mathrm{p}<0.05$, post hoc Duncan test $)$

\section{$\mathrm{Pb}$ and $\mathrm{Zn}$ concentration in shoots and roots in pot experiment}

Results showed that NS significantly $(\mathrm{P}<0.01)$ increased $\mathrm{Pb}$ and $\mathrm{Zn}$ concentrations in Stipa roots and shoots compared to the control (Table 6). Plants grown in NS500-amended pots had the maximum $\mathrm{Pb}\left(614.6 \mathrm{mgkg}^{-1}\right)$ in roots and $(672.0$ $\mathrm{mgkg}^{-1}$ ) in shoots. There was a significantly $(\mathrm{P}<0.01)$ effect of NS500 on Zn concentration in roots with maximum $\left(1708.0 \mathrm{mg} \mathrm{kg}{ }^{-1}\right)$ and the minimum $\mathrm{Zn}$ concentration $\left(768.8 \mathrm{mg} \mathrm{kg}^{-1}\right)$ recorded with the MSWC1\%, respectively. In addition, the maximum $\mathrm{Zn}$ in shoots of plants grown in NS500 amended pots was $1769.2 \mathrm{mgkg}^{-1}$ while the minimum value $\left(784.4 \mathrm{mgkg}^{-1}\right)$ occurred in MSWC1\% amended pots. Perhaps the most important reason for the increased $\mathrm{Pb}$ and $\mathrm{Zn}$ concentration in Stipa organs (in the treatment NS) is the reduced soil $\mathrm{pH}$. The solubility of heavy metals is often shown as a function of $\mathrm{pH}$ affected 
by the amount and kind of OM. In soil, the solution concentrations of metal contaminants tend to increase with decreasing $\mathrm{pH}$, mainly due to their displacement from exchangeable sites on solid surfaces by increasing the activity of hydrogen ions as there is a decrease in $\mathrm{pH}$. Accordingly, an increase in the availability of the contaminant for plant uptake may occur (RASKIN; ENSLEY, 1999). Addition of MSWC enhanced soil CEC and also reduced the absorption and accumulation of $\mathrm{Pb}$ and $\mathrm{Zn}$ in Stipa roots and shoots. Cations of heavy metals are often bonded to soil particles because of soil CEC. The negative charges are supplied by clay and OM of the soil. The binding affinity of cations reduces cation movement in vascular plants. Thus, a higher CEC of the soil leads to the greater the sorption and immobilization of the metals (GUPTA et al., 2013). In addition, the addition of MSWC enhanced $\mathrm{OM}$, which could bind $\mathrm{Pb}$ and $\mathrm{Zn}$ thus decreasing their solubility in the soil (SABIR et al., 2015). In the other words, an increase in the concentration of compost results in a subsequent decrease in heavy metal solubility. The release of phosphates, carbonates, and other salts during the decomposition of OM may lead to the formation of insoluble metal compounds and limit metal solubility (WALKER et al., 2003). Using organic amendments to soils may decrease the accessibility of heavy metals by transforming available fractions into the fractions associated with metal carbonates, oxides, and OM (WALKER et al., 2004). In general, organic amendments immobilized heavy metals through adsorption reactions which may be due to an increase in surface charge and the presence of metal binding compounds (GONDAR; BERNAL, 2009).

Table 6. Effect of MSWC and NS on concentrations of Pb and Zn in root and shoots of Stipa

\begin{tabular}{lllll}
\hline Treatments & Pb & \multicolumn{3}{l}{ Zn } \\
\hline & Root & Shoot & Root & Shoot \\
\hline Control & $410.0 \pm 9.06 \mathrm{c}$ & $455.2 \pm 18.03 \mathrm{~b}$ & $1612.0 \pm 6.1 \mathrm{c}$ & $1652.8 \pm 29.3 \mathrm{c}$ \\
MSWC 1\% & $318.0 \pm 13.7 \mathrm{~d}$ & $399.6 \pm 48.8 \mathrm{c}$ & $768.8 \pm 8.3 \mathrm{e}$ & $784.4 \pm 10.8 \mathrm{e}$ \\
MSWC 2\% & $402.8 \pm 22.7 \mathrm{c}$ & $422.4 \pm 21.8 \mathrm{bc}$ & $976.8 \pm 13.7 \mathrm{~d}$ & $990.4 \pm 23.08 \mathrm{~d}$ \\
NS250 $(\mathrm{mg} / \mathrm{kg})$ & $494.8 \pm 276.6 \mathrm{~b}$ & $645.6 \pm 9.2 \mathrm{a}$ & $1638.0 \pm 8.0 \mathrm{~b}$ & $1737.2 \pm 23.1 \mathrm{~b}$ \\
NS500 $(\mathrm{mg} / \mathrm{kg})$ & $614.6 \pm 16.3 \mathrm{a}$ & $672.0 \pm 8.7 \mathrm{a}$ & $1708.0 \pm 34.9 \mathrm{a}$ & $1769.2 \pm 13.3 \mathrm{a}$ \\
Duncan & $4.82^{* *}$ & $125.19^{* *}$ & $2984.0^{* *}$ & $2417.0^{* * *}$ \\
\hline
\end{tabular}

\section{Soil remediation}

$\mathrm{RF}$ is the ratio of metal accumulation in plants to that in the soils and indicates how efficiently metals are extracted from the soils and indirectly indicating mobilization or immobilization of metals in the soil. Higher RF indicates extraction efficiency of the metals from the soil due to increased solubilization of metals in the soil and vice versa (SABIR et al., 2015). Mean RF for $\mathrm{Pb}$ with MSCW was higher compared to the RF with NS500, suggesting that $\mathrm{Pb}$ was extracted more efficiently by the plants grown with MSCW (Table 7). Mean RF for $\mathrm{Zn}$ with MSCW2\% was higher compared to the RF with NS250, NS500, and control treatments indicating that $\mathrm{Zn}$ was extracted more efficiently by the plants grown with MSCW2\% (Table 7). RF for Zn was decreased with levels of MSWC1\% (0.29\%) and NS500\% (0.24\%) compared to that of the control $(0.4 \%)$. MSCW2\% due to having more nutrient and organic matter increased the growth and above-ground biomass. As a result, $\mathrm{RF}$ was increased, as well. The main reason for such a declined RF in plants grown in NS500 amended pots might be the high absorption of $\mathrm{Pb}$ and $\mathrm{Zn}$, which poses some stresses to the plants and thus lowers growth and dry weights of shoots.

Table 7. RF\% for metals studied with MSWC and NS applied at different levels in post-experiment soils

\begin{tabular}{lll} 
Treatments & Pb & Zn \\
\hline Control & $0.022 \pm 0.004 \mathrm{ab}$ & $0.4 \pm 0.045 \mathrm{~b}$ \\
MSWC 1\% & $0.026 \pm 0.005 \mathrm{a}$ & $0.29 \pm 0.043 \mathrm{c}$ \\
MSWC 2\% & $0.03 \pm 0.007 \mathrm{a}$ & $0.5 \pm 0.083 \mathrm{a}$ \\
NS250 $(\mathrm{mg} / \mathrm{kg})$ & $0.024 \pm 0.005 \mathrm{a}$ & $0.39 \pm 0.048 \mathrm{~b}$ \\
NS500 $(\mathrm{mg} / \mathrm{kg})$ & $0.016 \pm 0.005 \mathrm{~b}$ & $0.24 \pm 0.066 \mathrm{c}$ \\
Duncan & $4.18^{*}$ & $13.35^{* *}$ \\
\hline
\end{tabular}

$* *=$ significant at $\mathrm{P}<0.01, *=$ significant at $\mathrm{P}=0.01-0.05$; Mean values are reported with $\mathrm{SE}$ (Standard Error). Values within a column followed by the same letter do not differ significantly ( $\mathrm{p}<0.05$, post hoc Duncan test) 
In order to study the metal mobility in Stipa, TF and BCF were calculated (Table 8). TF represents the ability of metal transferring from roots to shoots of a plant. Plants with $\mathrm{TF}>1$ are classified as high-efficiency plants for metal translocation from the roots to shoots (MA et al., 2001). The ability of a plant to accumulate $\mathrm{Pb}$ and $\mathrm{Zn}$ is evaluated by the $\mathrm{BCF}$, where plants with $\mathrm{BCF}>1$ are accumulators, while those with $\mathrm{BCF}_{\text {shoot }}<1$ are excluders (YOON et al., 2006). In all treatments, the recorded values of TF for Stipa were greater than 1 for $\mathrm{Pb}$ and $\mathrm{Zn}$, indicating that the accumulation of $\mathrm{Pb}$ and $\mathrm{Zn}$ in the shoots is higher than that in the roots, probably due to the phytoremediation potential of Stipa. Stipa had $\mathrm{BCF}_{\text {shoot }}<1$ for $\mathrm{Pb}$, indicating that $\mathrm{Pb}$ accumulation in the soil is more than that in shoots. $\mathrm{BCF}_{\text {shoot }}>1$ for $\mathrm{Zn}$ (except treatment MSWC1\%). On the subject of phytoremediation strategies, plants with $\mathrm{TF}$ and $\mathrm{BCF}_{\text {shoot }}$ values $>1$ are suitable for phytoextraction. Thus, Stipa can be considered as a good candidate for phytoextraction of $\mathrm{Zn}$ from contaminated soils. Some reasons for the proportionality of this plant for Zn phytoextraction: 1) this plant is able to tolerate high soil $\mathrm{Zn}$ concentration and can be potentially used for phytoremediation of heavy-metalcontaminated soils (PULFORD; WATSON, 2003). 2) The TF of this plant was higher than 1.3) This plant is the most common species with a wide distribution on these $\mathrm{Pb}$ - and $\mathrm{Zn}$-polluted soils. 4) This plant has a large aboveground biomass and thus it can extract considerable amounts of $\mathrm{Zn}$ from the soil at each harvest. Sharifi et al. (2012) reported that plants including phytoremediation strategies, Acantholimon brachystachyum, Astragalus gossypinus, Stipa hohenackeriana, and Ephedra major a high TF can be potentially used for phytoextraction. Results were revealed $\mathrm{BCF}_{\text {root }}>1$ for $\mathrm{Zn}$ (except treatment of MSWC1\%). Therefore, Stipa can be considered as a suitable candidate for phytostabilization of $\mathrm{Zn}$ from contaminated soils, as well.

Table 8. Translocation factor (TF) and bioaccumulation factor (BCF) for S. hohenackeriana

\begin{tabular}{lllll}
\hline Metals & Treatments & TF & BCF $_{\text {Root }}$ & BCF $_{\text {Shoot }}$ \\
\hline \multirow{4}{*}{$\mathrm{Pb}$} & Control & $1.11 \pm 0.04 \mathrm{~b}$ & $0.068 \pm 0.004 \mathrm{ab}$ & $0.06 \pm 0.00 \mathrm{c}$ \\
& MSWC 1\% & $1.25 \pm 0.15 \mathrm{a}$ & $0.066 \pm 0.008 \mathrm{a}$ & $0.05 \pm 0.004 \mathrm{~d}$ \\
& MSWC 2\% & $1.05 \pm 0.10 \mathrm{~b}$ & $0.07 \pm 0.00 \mathrm{a}$ & $0.068 \pm 0.004 \mathrm{~b}$ \\
& NS250 $(\mathrm{mg} / \mathrm{kg})$ & $1.04 \pm 0.015 \mathrm{~b}$ & $0.11 \pm 0.004 \mathrm{a}$ & $0.1 \pm 0.005 \mathrm{a}$ \\
& NS500 $(\mathrm{mg} / \mathrm{kg})$ & $1.04 \pm 0.03 \mathrm{~b}$ & $0.11 \pm 0.005 \mathrm{~b}$ & $0.11 \pm 0.00 \mathrm{a}$ \\
& Duncan & $5.24^{* *}$ & $106.46^{* *}$ & $259.0^{* *}$ \\
\hline \multirow{3}{*}{$\mathrm{Zn}$} & Control & $1.02 \pm 0.017 \mathrm{~b}$ & $1.47 \pm 0.05 \mathrm{ab}$ & $1.44 \pm 0.036 \mathrm{c}$ \\
& MSWC 1\% & $1.02 \pm 0.023 \mathrm{~b}$ & $0.78 \pm 0.036 \mathrm{a}$ & $0.76 \pm 0.03 \mathrm{~d}$ \\
& MSWC 2\% & $1.01 \pm 0.028 \mathrm{~b}$ & $1.01 \pm 0.053 \mathrm{a}$ & $1.0 \pm 0.034 \mathrm{~b}$ \\
& NS250 (mg/kg) & $1.06 \pm 0.017 \mathrm{a}$ & $1.82 \pm 0.049 \mathrm{a}$ & $1.72 \pm 0.024 \mathrm{a}$ \\
& NS500 (mg/kg) & $1.03 \pm 0.017 \mathrm{ab}$ & $1.78 \pm 0.026 \mathrm{~b}$ & $1.72 \pm 0.041 \mathrm{a}$ \\
\hline$* * * 7^{*}$ & $301.9^{* *}$ & $798.8^{* *}$ \\
\hline
\end{tabular}

** = significant at $\mathrm{P}<0.01, *=$ significant at $\mathrm{P}=0.01-0.05$; Mean values are reported with $\mathrm{SE}$ (Standard Error). Values within a column followed by the same letter do not differ significantly ( $\mathrm{p}<0.05$, post hoc Duncan test)

\section{CONCLUSION}

Different amendments are widely used to increase heavy metals mobilization/immobilization and their bioavailability to plants, to improve plant growth, and enhance soil fertility. In the present study, MSWC and NS were applied at different ratios to evaluate their effects on lead and zinc uptake and accumulation in Stipa. Plants grown in NS500-amended pots had 33\% and 32\% higher $\mathrm{Pb}$ in roots and shoots compared to those grown in control pots, respectively. In comparison, in plant roots grown on MSWC1\%- and MSWC2\%amended pots it decreased to $22.4 \%$ and $1.7 \%$ compared to the control, respectively. $\mathrm{Zn}$ concentration in roots and shoots of plants grown in NS500-amended pots was $5.6 \%$ and $6.5 \%$ higher than those grown in control pots, respectively. However, for roots treated with MSWC1\% and MSWC2\%, Zn concentration decreased $52.3 \%$ and $39.4 \%$ compared to the control, respectively. In addition, in shoots $\mathrm{Zn}$ concentration decreased $52.5 \%$ and $40.0 \%$ compared to the control, respectively. Although MSWC decreased the uptake and accumulation of $\mathrm{Pb}$ and $\mathrm{Zn}$ in Stipa roots and shoots compared to the control, it improved the plant growth and dry weight and consequently increased $\mathrm{RF} \%$ and soil remediation compared to the NS. RF with MSWC was higher than that with NS, indicating that plants grown with MSWC, 
extracted more metals from the soil compared to NS amended plants. This difference might be due to the higher biomass production of the plants with MSWC. Stipa shoots contained a higher concentration of $\mathrm{Pb}$ and $\mathrm{Zn}$ compared to the roots irrespective of amendment applied.

In both pot and field experiments, Stipa showed tolerance to high $\mathrm{Pb}$ and $\mathrm{Zn}$ concentrations in the soil, and was able to take up and translocate $\mathrm{Pb}$ and $\mathrm{Zn}$ into roots and above-ground plant tissue and consequently be effective in $\mathrm{Pb}$ and $\mathrm{Zn}$ remediation in contaminated soils. Stipa in the pot experiment treated with MSWC and NS amendments accumulated much more $\mathrm{Pb}$ and $\mathrm{Zn}$ than those in the field experiment. In general, plants grown in pot experiments may contain higher concentrations of heavy metals than those grown in the field (FISCHEROVA et al., 2006). In general, the Stipa can be a suitable candidate for phytoremediation of heavy metals, especially for $\mathrm{Pb}$ and $\mathrm{Zn}$ contaminated soils. Although Stipa showed a high accumulation of $\mathrm{Pb}$ and $\mathrm{Zn}$ in plant tissues in the pot experiment, long-term field trials and the use of amendments MSWC and NS in the field are required to further investigate the potential of Stipa to remediate soils highly contaminated with $\mathrm{Pb}$ and $\mathrm{Zn}$.

RESUMO: Este estudo foi conduzido para avaliar a absorção, mobilidade e acumulação de $\mathrm{Pb}$ e $\mathrm{Zn}$ em Stipa hohenackeriana em experiências usando solo de campo em vaso e em campo. Além disso, os efeitos do Composto Municipal de Resíduos Sólidos (MSWC) (0, 1 e 2\%) e de nanopartículas de sílica (NS) (0, 250 e 500 mg/kg) na biomassa de Stipa, na disponibilidade de $\mathrm{Pb}$ e $\mathrm{Zn}$ no solo, e na absorção e acúmulo de $\mathrm{Pb}$ e $\mathrm{Zn}$ foram estudados usando experiências em vaso. Amostras de solo, raiz e brotos de Stipa foram coletadas do campo e da estufa e, após a secagem, a extração de $\mathrm{Pb}$ e $\mathrm{Zn}$ foi feita por digestão ácida. O Fator de Bioconcentração (BCF) e o Fator de Translocação (TF) foram calculados para determinar a eficiência de fitorremediação de $\mathrm{Pb}$ e $\mathrm{Zn}$. A quantidade de remediação de $\mathrm{Zn}$ e $\mathrm{Pb}$ pela Stipa a partir do solo foi determinada pelo Fator de Remediação (RF). Os resultados das experiências de campo mostraram que o nível de $\mathrm{Pb}$ e $\mathrm{Zn}$ diminuiu na seguinte ordem: solo $>$ broto $>$ raiz. Os resultados das experiências em vaso também mostraram que as plantas cultivadas em vasos corrigidos com NS500 apresentaram teores de $\mathrm{Pb} 33 \%$ e $32 \%$ maiores em raízes e brotos em comparação com vasos de controle, respectivamente. Em comparação, a concentração de $\mathrm{Pb}$ em raízes em vasos corrigidos com MSWC1\% e MSWC2\% diminuiu 22,4\% e 1,7\%, respectivamente. A concentração de Zn em raízes e brotos em vasos corrigidos com NS500 foi de 5,6\% e 6,5\% maior, respectivamente. No entanto, a concentração de Zn da raiz nos tratamentos de MSWC1\% e MSWC2\% diminuiu 52,3\% e 39,4\%, respectivamente. A concentração de $\mathrm{Zn}$ nos brotos diminuiu 52,5\% e 40,0\%, respectivamente. Embora o MSWC tenha diminuído a absorção e acumulação de $\mathrm{Pb}$ e Zn nas raízes e brotos de Stipa, melhorou o crescimento da planta e consequentemente aumentou o RF e a remediação do solo em relação ao NS. Assim, parece que aplicar MSWC e NS simultaneamente pode ser uma estratégia adequada com o objetivo de melhorar a capacidade de fitorremediação de Stipa nos solos contaminados com $\mathrm{Pb}$ e Zn. Em geral, a Stipa pode ser um candidato adequado para a acumulação de metais pesados, especialmente para solos contaminados com $\mathrm{Pb}$ e $\mathrm{Zn}$.

PALAVRAS-CHAVE: MSWC. NS. Fitorremediação. Metal pesado.

\section{REFERENCES}

ABBASI KHALAKI, M.; GHORBANI, A.; MOAMERI, M. Effects of silica and silver nanoparticles on seed germination traits of Thymus kotschyanus in laboratory conditions. Journal of Rangeland Science, v. 6, n. 3, p. 221-231, 2016.

ADRIANO, D. C.; WENZEL, W. W.; VANGRONSVELD, J.; BOLAN, N. S. Role of assisted natural remediation in environmental cleanup. Geoderma, v. 122, p. 121-142, 2004.

https://doi.org/10.1016/j.geoderma.2004.01.003

ALVARENGA, P.; GONCALVES, AP.; FERNANDES, RM.; VARENNES, A.; VALLINI, G.; DUARTE, E.; CUNHA-QUEDA, AC. Organic residues as immobilizing agents in aided phytostabilization: (I) Effects on soil chemical characteristics. Chemosphere, v. 74, p. 1292-1300, 2009.

https://doi.org/10.1016/j.chemosphere.2008.11.063 https://doi.org/10.1016/j.chemosphere.2008.11.006

ALVARENGA, P.; PALMA, P.; GONC, A. P.; FERNANDES, R. M.; CUNHA-QUEDA, A. C.; DUARTE E.; VALLINI, G. Evaluation of chemical and ecotoxicological characteristics of biodegradable organic residues for 
application to agricultural land. Environment International, v. 33, p. 505-513, 2007.

https://doi.org/10.1016/j.envint.2006.11.006

AMACHER, M. C.; SELIM, H. M. Mathematical models to evaluate retention and transport of chromium (VI) in soil. Ecological Modeling, v. 74, p. 205-230, 1994. https://doi.org/10.1016/0304-3800(94)90120-1

RASKIN, I.; ENSLEY, J. D. Phytoremediation of toxic metals: using plants to clean-up the environment. Wiley, New York, 1999. 304p.

CASTIGLIONE, M. R.; CREMONINI, R. Nanoparticles and higher plants. Caryologia, v. 62, p. 161165, 2009. https://doi.org/10.1080/00087114.2004.10589681

CLEMENS, S. Molecular mechanisms of plant metal tolerance and homeostasis. Planta, v. 212, p. 475-486, 2001. https://doi.org/10.1007/s004250000458

EBRAHIMI, M.; MADRID DIAZ, F. Use of Festuca ovina 1. in chelate assisted phytoextraction of copper contaminated soils. Journal of Rangeland Science, v. 4, n. 3, p.171-181, 2014.

FISCHEROVA, Z.; TLUSTOS, P.; SZAKOVA, J.; SICHOROVA, K. A comparison of phytoremediation capability of selected plant species for given trace elements. Environmental pollutants, v. 144, p. 93-100, 2006.

GONDAR, D.; BERNAL, M. P. Copper binding by olive mill solid waste and its organic matter fractions. Geoderma, v. 149, p. 272-279, 2009. https://doi.org/10.1016/j.geoderma.2008.12.005

GUPTA, D. K.; CORPAS, F. J.; PALMA, J. M. Heavy Metal Stress in Plants. Springer Heidelberg New York Dordrecht London, 2013. 245p. https://doi.org/10.1007/978-3-642-38469-1

ILER, R. K. The chemistry of silica: solubility, polymerization, colloid and surface properties, and biochemistry. John Wiley \& Sons, New York, USA, 1979. 866p.

KARUNAKARAN, G.; SURIYAPRABHA, R.; MANIVASAKAN, P.; YUVAKKUMAR, R.; RAJENDRAN, V.; PRABU, P.; KANNAN, N. Effect of nanosilica and silicon sources on plant growth promoting rhizobacteria, soil nutrients and maize seed germination. IET Nanobiotechnology, p. 1-8, 2013.

KIEKENS, L. Zinc, heavy metals in soils. 2 ed. London (UK): Blackie Academic and Professional, 1995. 305p.

LE, V. N.; RUI, Y.; GUI, X.; L. I, X.; LIU, S.; HAN, Y. Uptake, transport, distribution and Bio-effects of $\mathrm{SiO}_{2}$ nanoparticles in Bt-transgenic cotton. Journal of Nanobiotechnology, v. 12, p. 1-15, 2014. https://doi.org/10.1186/s12951-014-0050-8

LORESTANI, B.; CHERAGHI, M.; YOUSEFI, N. Phytoremediation Potential of Native Plants Growing on a Heavy Metals Contaminated Soil of Copper mine in Iran. World Acad of Sci Engin Tech, v. 5, p. 5-24, 2011.

MA, L. Q.; KOMAR, K. M.; TU, C.; ZHANG, W. A fern that hyperaccumulates arsenic. Nature, v. 409, p. 579-579, 2001. https://doi.org/10.1038/35054664

MACNAIR, M. R.; TILSTONE, G. H.; SMITH, S. E. Phytoremediation of contaminated soil and water. CRC Press, 2001. 408p.

MARSCHNER, H. Mineral Nutrition of Higher Plants. London (UK): Academic Press, 1995 889p.

MERTENS, J.; VERVAEKE, P.; SCHRIJVER, A.; LUYSSAERT, S. Metal uptake by young trees from dredged brackish sediment: limitations and possibilities for phytoextraction and phytostabilisation. Science of the Total Environment, v. 326, p. 209-215, 2004. https://doi.org/10.1016/j.scitotenv.2003.12.010 
MOAMERI, M.; JAFARI, M.; TAVILI, A.; MOTASHAREZADEH, B.; ZARE CHAHOUKI, M. A. Rangeland Plants Potential for Phytoremediation of Contaminated Soils with Lead, Zinc, Cadmium and Nickel (Case Study: Rangelands around National Lead \& Zinc Factory, Zanjan, Iran). Journal of Rangeland Science, v. 7, n. 2, p. 160-171, 2017.

MOGHIMI, J. Introduction some of important rangeland species for improvement of Iranian rangelands, Arvan press, 2005. 669p.

MOSLEHI, A.; FEKRI, M.; FOTOVAT, A. Effects of municipal solid waste compost and EDTA on the phytoremediation different levels of $\mathrm{CD}$ and $\mathrm{Pb}$ using Helianthus. Journal of Soil Researches, v. 28, n. 2, p. 421-431, 2014.

PAIS, I.; JONES, J. B. The Handbook of Trace Elements. ISBN 9781884015342 - CAT\# SL5344, 1997. 240p.

PAULKUMAR, K.; ARUNACHALAM, R.; ANNADURAI, G. Biomedical applications of organically modified bioconjugated silica nanoparticles. International Journal of Nanotechnology, v. 8, p. 653-663, 2011. https://doi.org/10.1504/IJNT.2011.041436

PENG, J. F.; YONG-HUI, S.; PENG, Y.; XIAO-YU, C.; GUANG-LEI, Q. Remediation of heavy metal contaminated sediment. Journal of Hazardous Materials, v. 161, p. 633-640, 2009.

https://doi.org/10.1016/j.jhazmat.2008.04.061

PULFORD, I. D.; WATSON, C. Phytoremediation of heavy metal-contaminated land by trees. A review Journal Environment International, v. 29, n. 4, p. 529-540, 2003. https://doi.org/10.1016/S01604120(02)00152-6

SABEEN, M.; MAHMOOD, Q.; IRSHAD, M.; FAREED, I.; KHAN, A.; ULLAH, F.; HUSSAIN, J.; HAYAT, Y.; TABASSUM, S. Cadmium Phytoremediation by Arundo donax L. from Contaminated Soil and Water.

BioMed Research International, p. 1-10, 2013. https://doi.org/10.1155/2013/324830

SABIR, M.; ALI. A.; REHMAN. M. Z.; HAKEEM, K. R. Contrasting Effects of Farmyard Manure (FYM) and Compost for Remediation of Metal Contaminated Soil. International Journal of Phytoremediation, p. 17, p. 613-621, 2015.

SABIR, M.; HANAFI, M. M.; AZIZ, T.; AHMAD, HR.; REHMAN, MZ.; SAIFULLAH, G.; HAKEEM, K. R. Comparative effect of activated carbon, pressmud and poultry manure on immobilization and concentration of metals in maize (Zea mays) grown on contaminated soil. International Journal of Agriculture and Biology, v. 15, n. 3 , p. 559-564, 2013.

SHARIFI, Z.; SAFARI SINEGANI, A. A.; SHARIATI, S. Potential of Indigenous Plant Species for the Phytoremediation of Arsenic Contaminated Land in Kurdistan (Iran). Soil and Sediment Contamination, v. 21, p. 557-573, 2012. https://doi.org/10.1080/15320383.2012.678951

SHARIFIAN, Z.; MAGHSOUDI MOOD, A. A.; MOHAMADI, N. Effect of different ratios of municipal solid waste compost on growth parameters and yield of Marigold (Calendula officinalis Moench.) and Daisy (Bellis Perennis L.). International journal of Advanced Biological and Biomedical Research, v. 2. n. 1, p. 43-50, 2014.

SOLTANPOUR, P. N. Determination of nutrient availability and elemental toxicity by AB-DTPA soil test and ICPS. In: Stewart BA, editor. Advances in soil science. New York (NY): Springer, p. 165-190, 1991. https://doi.org/10.1007/978-1-4612-3144-8_3 
SUN, Y. B.; ZHOU, Q. X.; XU, Y. M.; WANG, L.; LIANG, X. F. The role of EDTA on cadmium phytoextraction in a cadmium hyperaccumulator Rorippa globosa. Journal of Environmental Chemistry and Ecotoxicology, v. 3, n. 3, p. 45-51, 2011.

WALKER, D.J.; CLEMENTE, R.; BERNAL, M. P. Contrasting effects of manure and compost on soil pH, heavy metal availability and growth of Chenopodium album $\mathrm{L}$. in a soil contaminated by pyritic mine waste. Chemosphere, v. 57. n. 3, p. 215-224, 2004. https://doi.org/10.1016/j.chemosphere.2004.05.020

WALKER, D. J.; CLEMENTE, R.; ROIG, A.; BERNAL, M. P. The effects of soil amendments on heavy metal bioavailability in two contaminated Mediterranean soils. Environmental Pollution, v. 122, n. 2, p. 303-312, 2003. https://doi.org/10.1016/S0269-7491(02)00287-7

WILSON, S. B.; MECCA, L. K.; STOFFELLA, P. J.; GRAETZ, D. A. Using compost for container production of ornamental hammock species native to Florida. Native Plants Journal, v. 5, n. 2, p. 186-194, 2004. https://doi.org/10.2979/NPJ.2004.5.2.186

YOON, J.; CAO, X.; ZHOU, Q.; MA, L. Q. Accumulation of $\mathrm{Pb}, \mathrm{Cu}$, and $\mathrm{Zn}$ in native plants growing on a contaminated Florida site. Science of the Total Environment, v. 368, p. 456-464, 2006.

https://doi.org/10.1016/j.scitotenv.2006.01.016

YUVAKKUMAR, R.; ELANGO, V.; RAJENDRAN, V.; KANNAN, N. S.; PRABU, P. Influence of nanosilica powder on the growth of maize crop (Zea mays L.). International Journal of Green Nanotechnology, v. 3, p. 180-190, 2011. https://doi.org/10.1080/19430892.2011.628581 